\title{
Otomatisasi Tugas Dalam Proses Pendaftaran dan Pemberkasan Mahasiswa Baru
}

\author{
Rinda Cahyana ${ }^{1}$, Pebby Mohamad Ikhsan Saddam ${ }^{2}$ \\ Jurnal Algoritma \\ Sekolah Tinggi Teknologi Garut \\ J1. Mayor Syamsu No. 1 Jayaraga Garut 44151 Indonesia \\ Email : jurnal@itg.ac.id \\ ${ }^{1}$ rindacahyana@itg.ac.id \\ 21606073@itg.ac.id
}

\begin{abstract}
Abstrak - Perguruan tinggi memiliki peran penting dalam pembangunan kompetensi dan karakter pelaku pariwisata. Pengembangan sumber daya perguruan tinggi mempengaruhi pembangunan tersebut. Di antara sumber daya yang digunakan untuk efisiensi layanan kampus adalah teknologi informasi. Penelitian lima tahun terakhir di Sekolah Tinggi Teknologi Garut telah menyentuh topik pengembangan sumber daya teknologi informasi yang berkaitan dengan penerimaan pesetra didik baru pada jenjang pendidikan dasar, menengah, dan tinggi. Penelitian ini bertujuan untuk mengembangkan teknologi yang sama untuk penerapan di perguruan tinggi yang belum dilakukan oleh penelitian sebelumnya. Pengembangannya menggunakan metode Rational Unified Process sampai fase construction. Penelitian menghasilkan Sistem Informasi Penerimaan Mahasiswa Baru yang membantu panitia dalam pengelolaan berkas pendaftaran dan mengurangi usaha dan waktu pendaftar dalam proses pendaftaran. Penelitian ini juga melengkapi penelitian sebelumnya dengan menghadirkan fitur tes ujian masuk yang digunakan dalam proses seleksi peserta didik baru. Hasil tes tersebut merupakan data masukan dalam proses penentuan kelulusan.
\end{abstract}

Kata Kunci - Calon Mahasiswa; Efisiensi; Pendaftaran; Sistem Informasi.

\section{PENDAHULUAN}

Kabupaten Garut merupakan salah satu tujuan wisata di provinsi Jawa Barat. Masyarakat yang berpusat pada industri pariwisata membangun kompetensi dan karakter pelaku pariwisatanya dengan kegiatan pendidikan dan keagamaan [1][2]. Pembangunan kompetensi atau kemampuan dan karakter atau watak tersebut merupakan fungsi dari pendidikan tinggi, sebagaimana tersebut dalam pasal 4 Undang-Undang Republik Indonesia nomor 12 tahun 2012. Perguruan tinggi selaku penyelenggara pendidikan tinggi mengubah masyarakat menggunakan sumber daya yang meliputi teknologi, ilmu pengetahuan dan sumber daya manusia [3]. Sumber daya tersebut mempengaruhi proses pembangunan kemampuan dan watak pelaku pariwisata.

Teknologi informasi sebagai sumber daya teknologi pada perguruan tinggi berfungsi untuk meningkatkan layanan kampus dan memenuhi kebutuhan informasi, dengan tujuan efisiensi dan efektifitas pengajaran, penelitian, dan pengabdian kepada masyarakat [4]. Di antara layanan yang diselenggarakan oleh kampus adalah PMB (Penerimaan Mahasiswa Baru). Dalam prakteknya, panitia PMB berhadapan dengan masalah pengelolaan berkas dan data pendaftar; dan peserta harus menyediakan waktu, tenaga dan finansial yang tidak sedikit saat melakukan prosesnya [5]. Kampus mengembangkan layanan PMB daring untuk menjawab permasalahan tersebut dan meningkatkan kenyamanan pendaftar. Layanan tersebut menyediakan cara akses informasi dan pendaftaran secara self-service. Penerapan self-service di kampus akan meningkatkan kepuasan pengguna informasi apabila tersedia platform tekologi yang menyediakan waktu dan akses informasi akademik tanpa batas [6][7]. 
Penelitian terkait topik pengembangan teknologi PPDB (Penerimaan Peserta Didik Baru) di Sekolah Tinggi Teknologi Garut dapat ditelusuri 5 tahun terakhir. Sekolah Tinggi Teknologi Garut telah melakukan penelitian teknologi tersebut pada jenjang pendidikan dasar, menengah, dan tinggi. Pada tahun 2015, Suhendar meneliti teknologi dengan basis web di Sekolah Menengah Kejuruan Ciledug Garut yang menyediakan informasi periode pendaftaran, biaya pendaftaran, profil jurusan, formulir pendaftaran, konfirmasi pembayaran pendaftaran, dan pengumuman kelulusan secara daring [8]. Pada tahun 2017, Rahayu dan Suandi meneliti teknologi yang sama di Sekolah Menengah Atas Negeri 14 Garut [1]. Mulyani dan Ramadhan meneliti teknologi yang sama di Sekolah Dasar Islam Terpadu PERSIS Garut [9]. Pada tahun 2019, Heryanto, Sutedi dan Cahyana mengembangkan sistem pemantauan digital berbasis mobile yang menyajikan informasi prospek calon peserta didik baru kepada pembuat keputusan berdasarkan data yang dikumpulkan oleh tim roadshow PT (Perguruan Tinggi) [10]. Terdapat ruang kosong penelitian Sekolah Tinggi Teknologi Garut sebagaimana tampak pada tabel 1. Penelitian ini bertujuan untuk mengisi ruang kosong tersebut dengan mengembangkan sistem informasi untuk efisiensi proses pendaftaran dan pemberkasan mahasiswa baru.

Tabel 1: Roadmap Penelitian

\begin{tabular}{|c|c|c|c|c|c|c|}
\hline Status & Peneliti & Tahun & $\begin{array}{c}\text { Basis } \\
\text { Platform }\end{array}$ & $\begin{array}{c}\text { Sasaran } \\
\text { Pengguna }\end{array}$ & $\begin{array}{c}\text { Penerimaan } \\
\text { Peserta Didik }\end{array}$ & $\begin{array}{c}\text { Tes Ujian } \\
\text { Masuk }\end{array}$ \\
\hline \multirow{4}{*}{ Baseline } & Suhendar & 2015 & Web & SMK & Ada & Tidak Ada \\
\hline & Rahayu \& Suandi & 2017 & Web & SMA & Ada & Tidak Ada \\
\hline & $\begin{array}{l}\text { Mulyani \& } \\
\text { Ramadhan }\end{array}$ & 2017 & Web & SD & Ada & Tidak Ada \\
\hline & $\begin{array}{l}\text { Heryanto, Sutedi } \\
\text { dan Cahyana }\end{array}$ & 2019 & Android & PT & Ada & Tidak Ada \\
\hline Gap & & 2020 & Web & PT & Ada & Ada \\
\hline
\end{tabular}

\section{METODE PENELITIAN}

Penelitian ini menggunakan metode pengembangan software RUP (Rational Unified Process), mengikuti Susilowati, Susliansyah dan Aria yang telah mengembangkan Sistem Informasi PPDB menggunakan RUP [11][12]. Aktivitas RUP berfokus pada pengembangan model menggunakan UML (Unified Modeling Language) dengan konsep object-oriented. RUP meliputi fase iteratif, meliputi inception, elaboration, construction dan transition. Penelitian ini dibatasi sampai fase construction. Secara keseluruhan, tahapan dan aktivitas penelitiannya sebagaimana tampak pada Gambar 1.

Tahapan pertama adalah tahapan Literature Survey, tahapan ini dilakukan untuk memahami konsep penelitian dengan melakukan literature searching yaitu mengumpulkan informasi yang telah diterbitkan dan berhubungan dengan subjek penelitian kemudian literature review untuk mendapatkan pertanyaan, tujuan, dan roadmap penelitian serta mengidentifikasi metode dan strategi penelitian. Tahapan kedua adalah Inception, tahap ini adalah fase pertama dalam metodologi pengembangan software RUP yang mempunyai 2 aktivitas yaitu actors identification untuk menentukan partisipan dan perannya pada sistem yang dibuat dan aktivitas identifikasi proses bisnis dengan acuan sistem informasi PMB Sekolah Tinggi Teknologi Garut yang kemudian dilakukan analisis untuk membentuk proses bisnis yang akan digunakan. Tahap ketiga adalah Elaboration, pada tahapan ini dilakukan pemodelan visual menggunakan UML dengan merancang use case diagram untuk identifikasi skenario aktor, merancang activity diagram untuk memodelkan aliran kerja pada sistem, merancang sequence diagram untuk menggambarkan kelakuan objek yang saling berinteraksi dengan sistem, merancang class diagram untuk memetakan struktur sistem berdasarkan kelas yang dibuat, merancang struktur menu yang tersedia untuk aktor dan merancang interface yang dibutuhkan. Tahap keempat adalah Construction, tahapan ini adalah fase pembuatan perangkat lunak dalam RUP, pada fase ini dilakukan implementasi kode kedalam bahasa pemrograman yang sesuai dengan pemodelan yang dilakukan pada tahap elaboration, implementasi sistem informasi ini menggunakan platform web dengan bahasa skrip PHP dengan framework lavaren dan menggunakan sistem database SQL MySql, pada tahapan ini menghasilkan perangkat 
lunak yang sudah jadi. Tahap kelima adalah Complete Report, tahapan ini mempunyai aktivitas penyusunan laporan akhir penelitian dengan menyusun laporan dan membuat poster penelitian.

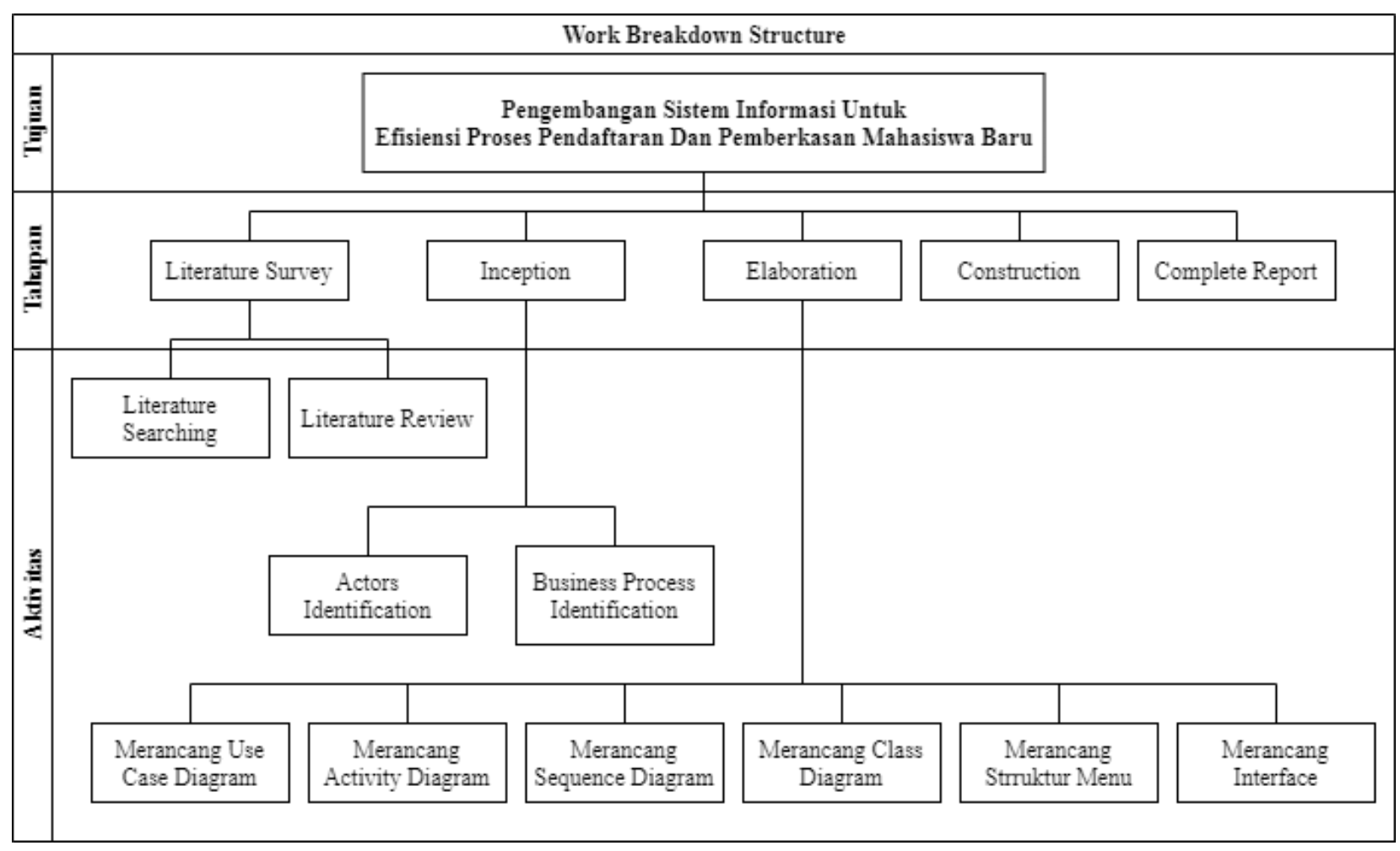

Gambar 1: Work Breakdown Structure

\section{HASIL DAN PEMBAHASAN}

Penelitian ini telah mewujudkan efisiensi dalam proses pendaftaran dan pemberkasan mahasiswa baru. Sebelumnya, calon mahasiswa mendatangi kampus untuk mengisi dan menyerahkan berkas-berkas yang dibutuhkan. Dengan menggunakan sistem informasi penerimaan mahasiswa baru, calon mahasiswa dapat mengisi dan menyerahkan berkas-berkas tersebut secara online seperti yang terlihat pada Gambar 2.

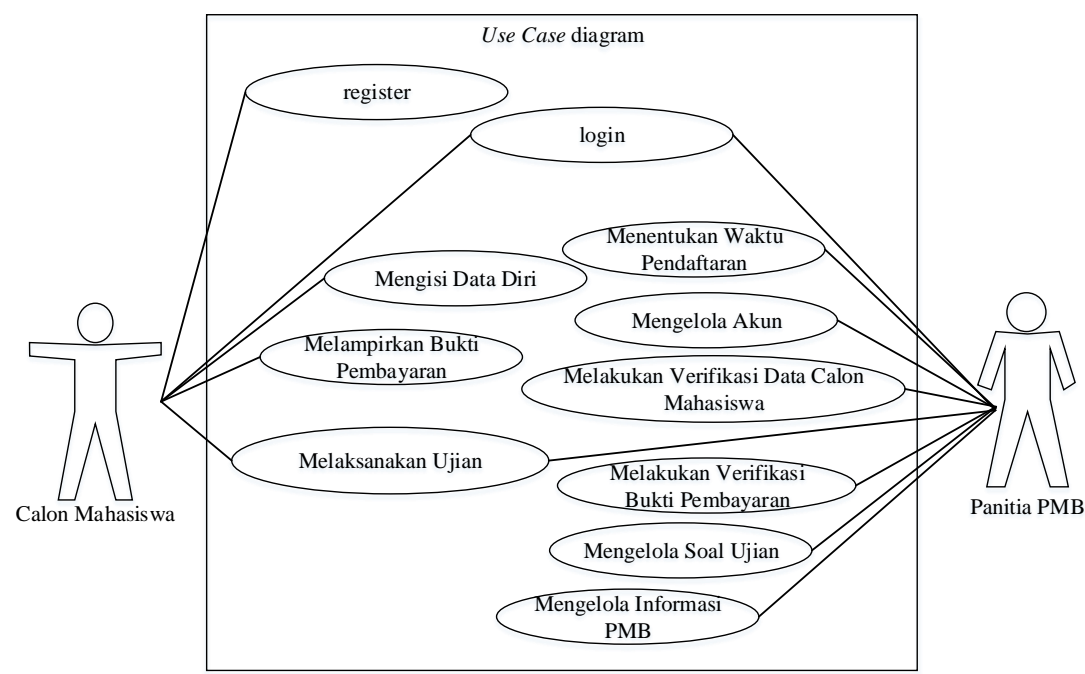

Gambar 2: Diagram Usecase 
Calon mahasiswa hanya bisa mendaftar pada waktu yang ditentukan, jika calon mahasiswa membuka web sebelum waktu pendaftaran dibuka atau setelah waktu penutupan pendaftaran maka form registrasi tidak akan tersedia. Panitia mengatur waktu pembukaan dan penutupan pendaftaran terlebih dahulu sebelum calon mahasiswa bisa mendaftar sebagaimana tampak dalam activity diagram pada Gambar 3.

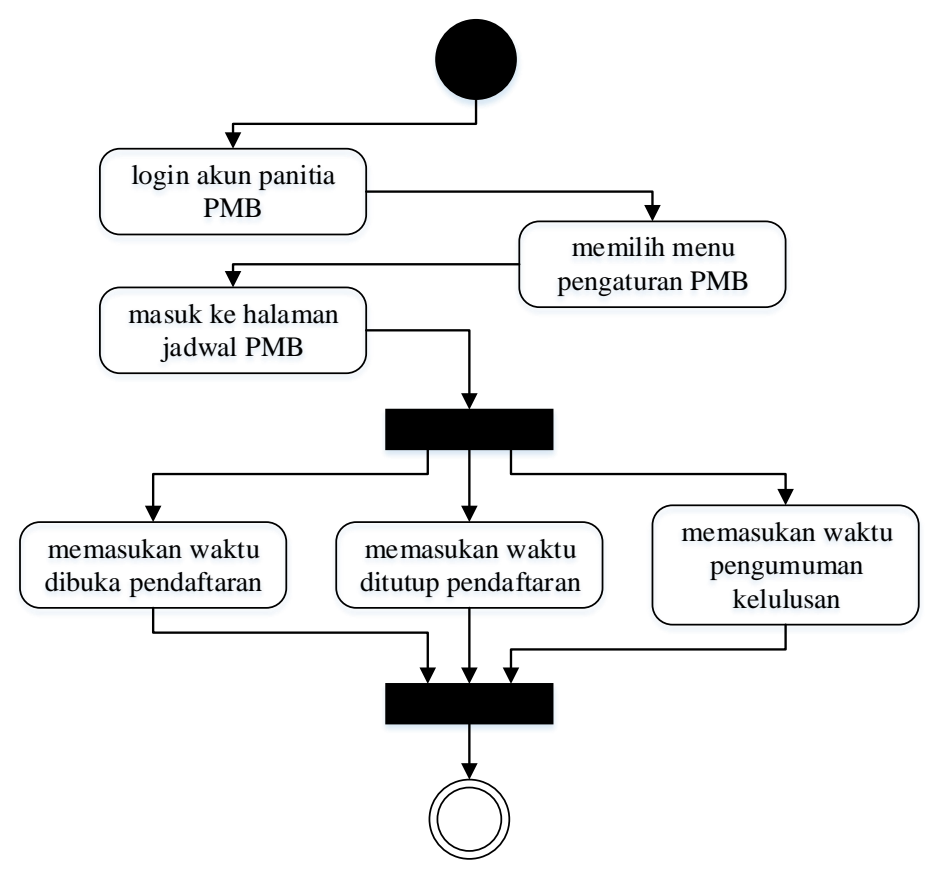

Gambar 3: Activity Diagram Menentukan Waktu Pendaftaran

Calon mahasiswa harus melampirkan bukti pembayaran biaya pendaftaran, mengisi formulir data diri dan melampirkan dokumen pendaftaran. Selanjutnya panitia PMB akan melakukan verifikasi data calon mahasiswa sebagaimana tampak dalam sequence diagram pada Gambar 4.

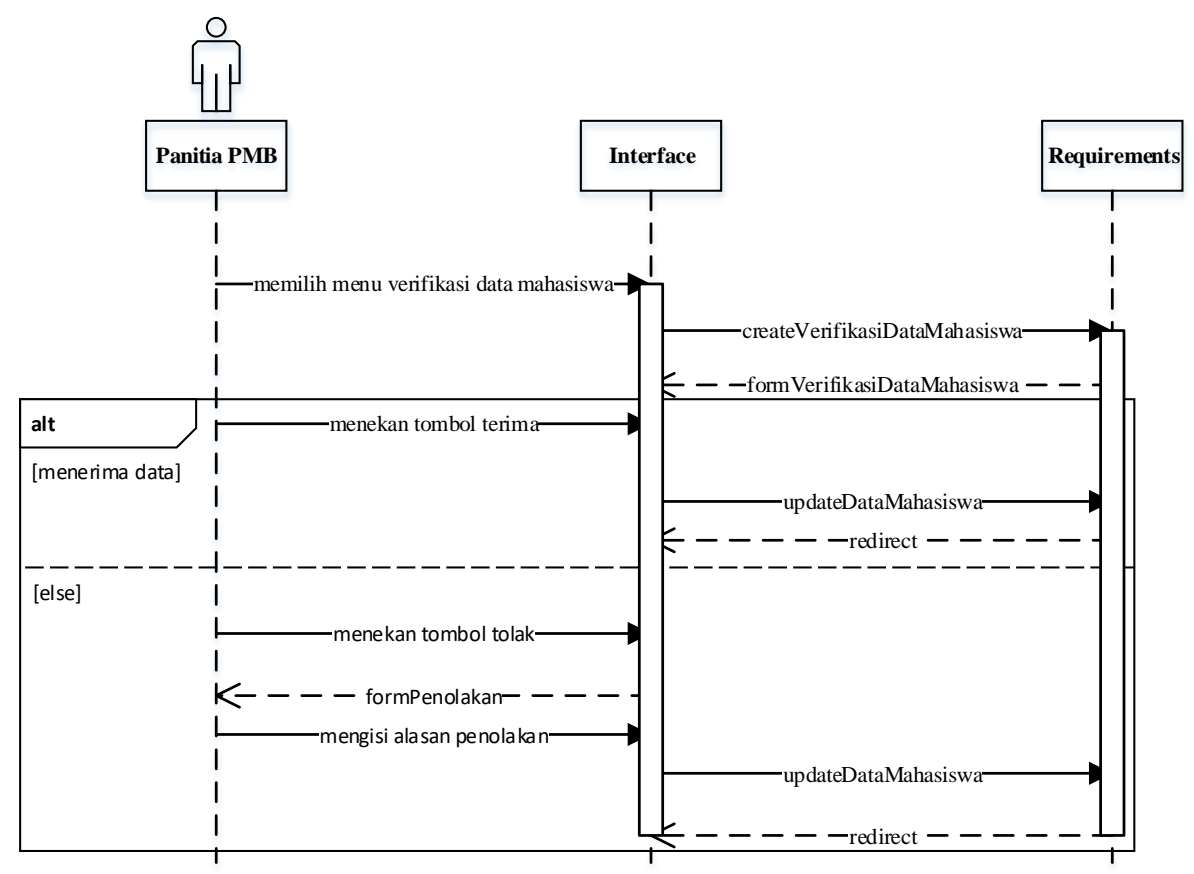

Gambar 4: Sequence Diagram Verifikasi Data Calon Mahasiswa 
Setelah melakukan verifikasi pembayaran biaya pendaftaran, calon mahasiswa dapat melakukan ujian. Panitia PMB membuat soal ujian dan mengatur syarat kelulusan calon mahasiswa untuk setiap jurusan. Semua data dan aktivitas terkait sistem informasi PMB sebagaimana tersaji pada Gambar 5.

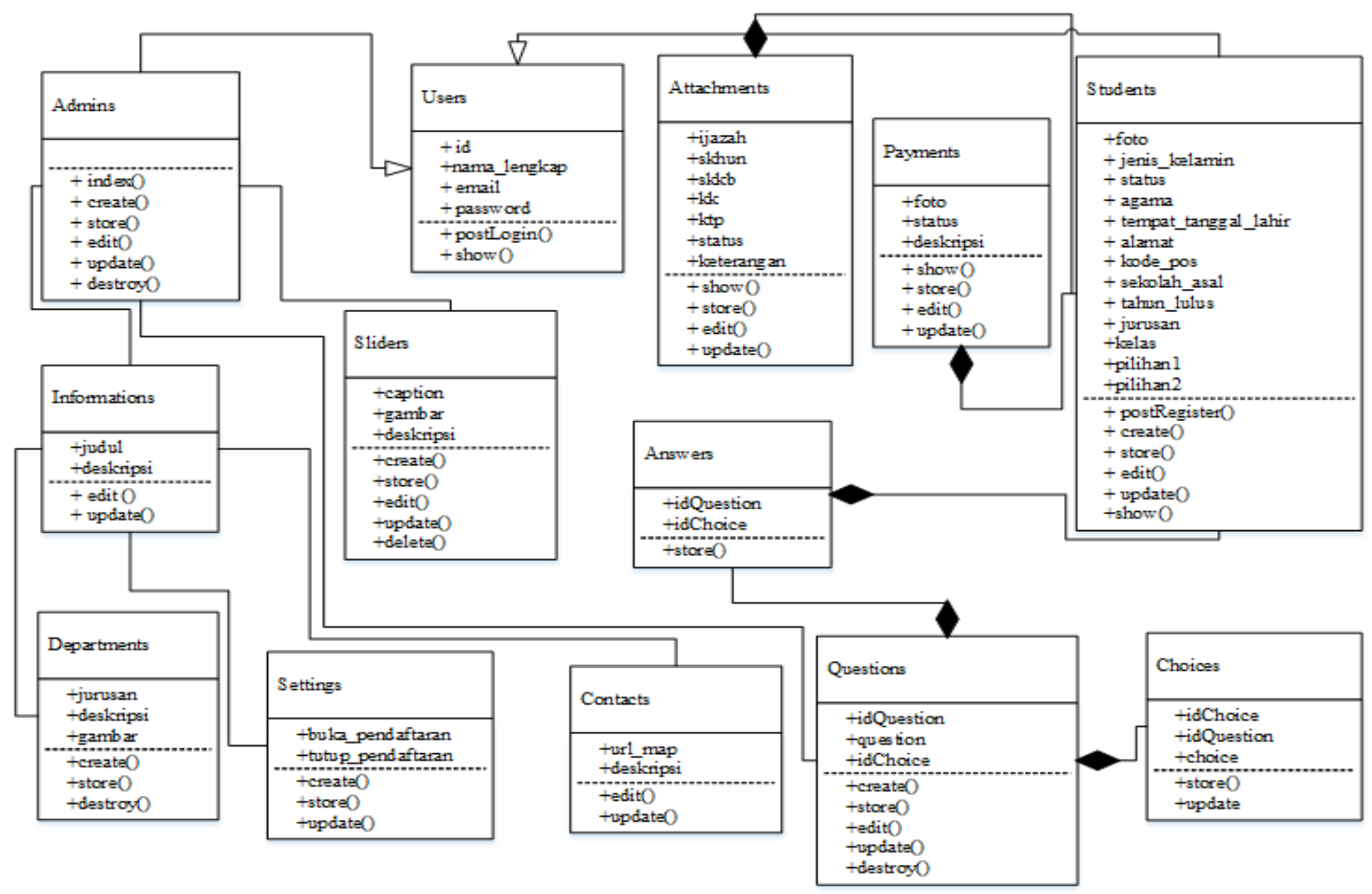

Gambar 5: Class Diagram

Setelah calon mahasiswa melakukan ujian, daftar nama calon mahasiswa yang lulus ujian akan ditampilkan di halaman utama web dan akan terus berubah sampai waktu penutupan pendaftara, jika nama calon mahasiswa menghilang dari daftar nama yang ada di landingpage maha calon mahasiswa tersebut tidal berhasil diterima dan bisa langsung mendaftar di perguruan tinggi lain tanpa harus menunggu hasil kelulusan, nama calon mahasiswa yang muncul di landingpage setelah penutupan pendaftaran adalah calon mahasiswa yang berhasil diterima seperti yang terlihat pada tampilan landingpage Gambar 6. 


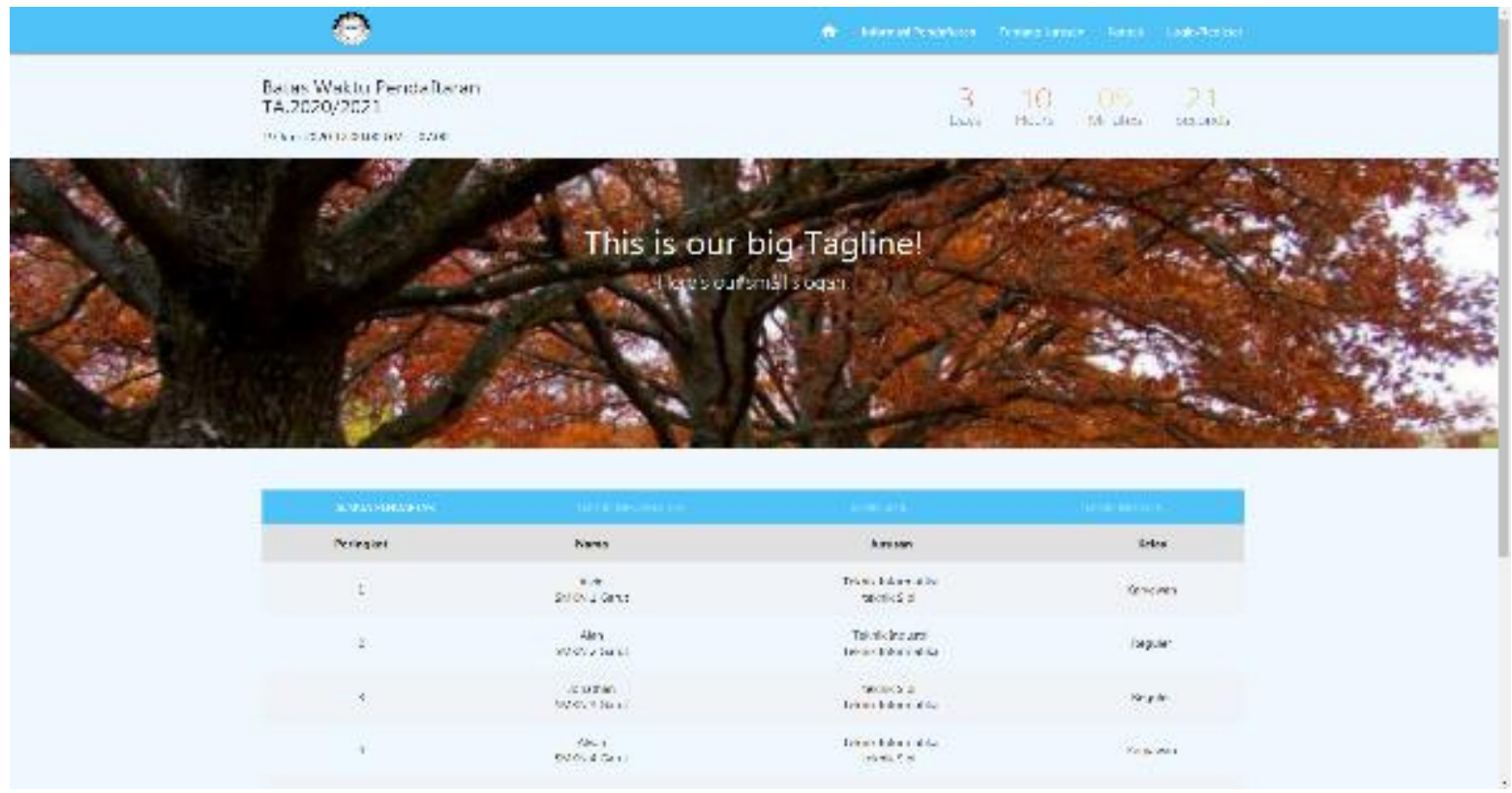

Gambar 6: Landingpage

\section{KESIMPULAN}

Berdasarkan hasil penelitian dapat disimpulkan bahwa Penelitian ini menghasilkan Teknologi yang mewujudkan efisiensi waktu dan usaha pemberkasan dan pendaftaran dan proses penerimaan mahasiswa baru. Di harapkan penelitian berikutnya dapat mengakomodasi alternatif jalur pendaftaran lainnya dan menyediakan fitur notifikasi kelulusan melalui email.

\section{DAFTAR PUSTAKA}

[1] S. Rahayu and W. Suandi, "Perancangan Sistem Informasi Penerimaan Siswa Baru Berbasis Web di Sekolah Menengah Atas Negeri 14 Garut," J. Algoritm., vol. 14, no. 2, pp. 255-262, 2017.

[2] R. Cahyana, D. Kurniadi, Y. Pariyatin, and A. Susetyaningsih, "The TIGER society framework in the scope of information technology infrastructure," 2019, doi: 10.1088/1742-6596/1402/6/066102.

[3] T. Suryani, "Penguatan Peran Perguruan Tinggi dalam Pemberdayaan Masyarakat di Era Industri 4.0," 2018.

[4] W. Darmalaksana, M. A. Ramdhani, R. Cahyana, and A. S. Amin, "Strategic Design of Information System Implementation at University," Int. J. Eng. Technol., vol. 7, no. 2.29, pp. 787-791, 2018.

[5] A. Hidayati, "Perancangan Dan Pembuatan Aplikasi Pendaftaran Mahasiswa Baru," J. ELTEK, pp. 6778, 2017.

[6] R. Cahyana, S. Rahayu, and E. Satria, "Revealing student satisfaction related to academic information services using the Kano model," J. Phys. Conf. Ser., 2019.

[7] K. Arianto, Mukhammad Agus; Munir, Sirojul; Khotimah, "Analisis dan Perancangan Representational State Transfer (REST) Web Service Sistem Informasi Akademik STT Terpadu Nurul Fikri Menggunakan YII Framework," J. Teknol. Terpadu, 2016.

[8] C. Suhendar, "Rancang Bangun Sistem Informasi Penerimaan Siswa Baru Berbasis web," J. Algoritm., vol. 12, no. 2, pp. 588-595, 2015.

[9] A. Mulyani and F. N. Ramadhan, "Rancang Bangun Sistem Informasi Penerimaan Santri Baru Di Sekolah Dasar Islam Terpadu Persis Tarogong Berbasis Web,” J. Algoritm., vol. 14, no. 2, pp. 288-297, 2017.

[10] D. Heryanto, A. Sutedi, and R. Cahyana, "The proposed information system design to improve new 
students," J. Phys. Conf. Ser., vol. 1402, no. 2, p. 022080, 2019.

[11] K. Nasional, I. Sosial, S. Susilowati, R. R. Aria, P. Peserta, and D. Baru, "Penerapan Metode Rational Unified Process Pada Sistem Informasi Penerimaan Peserta Didik Baru," Konf. Nas. Ilmu Sos. dan Teknol., pp. 332-338, 2014.

[12] M. Sutedi; Agarina, "Implementasi Rational Unified Process Dalam Rancang Bangun Sistem Informasi Penjualan Hasil Bumi Berbasis Web Pada Cv. Aneka Mandiri Lestari Bandar Lampung,” J. Sist. Inf. dan Telemat., vol. 8, no. 2, pp. 181-187, 2017. 